 \\ z Filologii Polskiej i Słowiańskiej
}

\section{Uzus a praktyka leksykograficzna (na przykładzie czasownika dedykować we współczesnej polszczyźnie)}

W numerze 2 czasopisma "Język Polski” z roku 2013, w dziale Ze zjawisk współczesnego języka opublikowana została notka pod tytułem Składniowe paradoksy leksykalnych kalk (Miodek, 2013, s. 118), której autorem jest profesor Jan Miodek. W tekście tym autor, analizując zdanie „Rachunek ten jest dedykowany na budowę szpitala”, dochodzi do wniosku, że takie użycie stanowi przejaw swoistego rodzaju paradoksalnej kontaminacji. Jej istotą jest połączenie imiesłowowej formy czasownika dedykować, którego nowe znaczenie zostało zapożyczone z języka angielskiego, i schematu łączliwości składniowej czasownika przeznaczać z właściwą mu konstrukcją przyimkową na coś ${ }^{1}$. Stwierdzenie to, bezsprzecznie słuszne, wydaje się jednak niewystarczające.

${ }^{1}$ Ustalenia powyższe powtórzył autor w popularnonaukowym tekście, który ukazał się na łamach „Gazety Wyborczej”. Artykuł o charakterze popularyzatorskim zawiera ponadto krytykę bezrefleksyjnego przejmowania nowego znaczenia, które skutkuje zanikiem warian-

This is an Open Access article distributed under the terms of the Creative Commons Attribution 3.0 PL License (creativecommons.org/licenses/by/3.0/pl/), which permits redistribution, commercial and non-commercial, provided that the article is properly cited. (c) The Author(s) 2016. 
Monika Biesaga Uzus a praktyka leksykograficzna (na przykładzie czasownika dedykować...

Problem użyć czasownika dedykować we współczesnym języku polskim jest o wiele szerszy i bardziej złożony.

Jeżeli chodzi o dotychczasową praktykę definicyjną słowników dzisiejszej polszczyzny, wydanych po roku 1989, to zasadniczo odnotowują one jedno znaczenie czasownika dedykować, por.

SWJP (1996, s. 159): poświęcić, ofiarować komuś coś (zwykle utwór muzyczny, literacki, dzieło sztuki): Dedykować komuś utwór, obraz, płytę. Zadedykować komuś piosenkę.

PSWP (1996, s. 159): poświęcać komuś utwór, dzieło, jakiś z punktu widzenia ofiarodawcy i obdarowanego wartościowy przedmiot: A teraz zaśpiewam piosenkę dedykowaną mojej zmarłej siostrze. Poemat ten dedykował Słowacki swojej matce. Połączenia: dedykować utwór (dzieło) pamięci matki, ojca, żony itd. uczcić pamięć zmarłej matki, żony, zmarłego ojca itd. utworem (dziełem).

USJP (2003, s. 564): książk. „ofiarować, ofiarowywać, poświęcić, poświęcać komuś coś, np. wiersz, powieść, film": Tę piosenkę dedykuję moim rodzicom.

ISJP (2000, s. 249): Jeśli ktoś dedykował komuś swoje dzieło, to symbolicznie ofiarował mu je, np. umieszczając na nim specjalny napis, i w ten sposób wyraził swój szacunek, wdzięczność, miłość itp. dla tej osoby. Kompozytor dedykowat tę symfonię swojej żonie.

WSJP KWN (2012, s. 141): poświęcić, ofiarować komuś utwór², np. wiersz, film, piosenkę: Wszystkie swoje wiersze dedykował żonie.

Jak widać, leksykografowie - poza częstym stosowaniem definicji wielokrotnej (poświęcić, ofiarować), świadczącej o wahaniu co do sensu wyrazu oraz o niemożności poradzenia sobie z wieloznacznością jednostki leksykalnej (por. Bańko, 2001, ss. 103-108) - formułując eksplikację i dopasowując do niej preparowane kolokacje czy zdania, na myśli mieli przede wszystkim szeroko pojęte dzieła o charakterze artystycznym (utwory literackie i muzyczne, dzieła sztuki, filmy). Choć autorzy USJP i SWJP posługują się pojemną etykietą coś, egzemplifikacji językowej odnoszącej się do obiektów innych niż dzieła artystyczne brak.

Jeżeli przeanalizujemy użycia czasownika dedykować w wersji pełnej Narodowego Korpusu Języka Polskiego (NKJP, b.d.), odnajdziemy bez większego problemu wiele przykładów realizacji znaczenia semantycznie podstawowego

tywności stylistycznej, czyli możliwości przemiennego posługiwania się bliskoznacznymi określeniami (Miodek, 2014).

${ }^{2}$ Jak się wydaje, autorzy słownika popełnili tu niezamierzony błąd. W polszczyźnie ogólnej dzieła filmowe nie przynależą do kategorii utworów. Co ciekawe, są składową tej kategorii w języku prawnym oraz prawniczym, zwłaszcza dotyczącym praw autorskich. 
we współczesnej polszczyźnie. Są one zgodne z opisem słownikowym, odnoszą się bowiem do ofiarowywanych komuś dzieł artystycznych lub wykonań tychże dzieł. Składniowo formy wyrazowe reprezentować będą kategorię orzeczeń bądź ich składowych (orzeczników), jak również przydawek, np.

Ma lat pięćdziesiąt siedem, kiedy dedykuje królowej rozprawę O równości mężczyzn i białych głów $[\ldots]^{3}$.

Dwa koncerty artysta dedykowal paniom w dniu ich święta ${ }^{4}$.

Kilka dni temu w polskiej ambasadzie w Londynie zaprezentowano II tom książki o polsko-brytyjskiej współpracy w tamtych latach. Jego pomysłodawcą był Jan Nowak-Jeziorański, któremu tom jest dedykowany ${ }^{5}$.

Jest to broszura dedykowana dla Lelewela, napisana pod niewątpliwym jego wpływem i czarem ${ }^{6}$.

To jednak nie wszystko, gdyż w korpusie znajdziemy przykłady użyć, w których to, co symbolicznie ofiarowywane komuś, wykracza dalece poza kategorię dzieł sztuki i wykonań artystycznych. Szczególnie owo rozszerzanie, rozpychanie wyjściowego znaczenia widoczne jest w tekstach poświęconych sportowi. Tutaj następujące przykłady:

Gola dedykuję mojemu koledze Grześkowi Lorkowi, któremu niedawno urodziła się córeczka?.

Moje dzisiejsze zwycięstwo dedykuję wszystkim tym, którzy się nie poddająa

Swój tegoroczny start w Biegu Piastów Jan Chowański dedykował zmarłemu niedawno Jerzemu Maklesowi, od którego niejednego się nauczył i z którym kilkakrotnie współpracował przy organizacji ostrzeszowskiego crossu?

Jak widać, najnowsze słowniki języka polskiego powinny stosownie poszerzyć definicję w odniesieniu do klasy obiektów dedykowanych, do której należeć będą nie tylko dzieła i wykonania artystyczne, lecz także wszelkiego

${ }^{3}$ NKJP (b.d.): Józef Hen, Ja, Michał z Montaigne?, 2009 [Dane bibliograficzne cytowanych fragmentów podaję za NKJP - przyp. M. B.].

${ }^{4}$ NKJP (b.d.): Miejskie sprawy, „Gazeta Poznańska”, 2005-03-09.

5 NKJP (b.d.): EC/IA/PAP, Expressem, „Super Express”, 2006.

6 NKJP (b.d.): Marian Henryk Serejski, Europa a rozbiory Polski, 2009.

7 NKJP (b.d.): (bh), Skuteczny powrót Hajca, „Dziennik Polski”, 2008-04-07.

8 NKJP (b.d.): Wojciech Nowosielski, Narciarstwo alpejskie. PŚ, „Gazeta Wyborcza”, 1995-02-21.

9 NKJP (b.d.): W. Juszczak, Jan Chowański znów w Biegu Piastów, „Czas Ostrzeszowski”, nr 11, 2005. 
rodzaju działania i osiągnięcia wymagające wysiłku, następnie symbolicznie poświęcane bliskim bądź mistrzom.

Inną sprawą jest tutaj pewien kontekst społeczny, w jakim obserwujemy rozszerzenie znaczenia. $Z$ jednej strony akt dedykowania zwraca uwagę na twórcę osiągnięcia, wymusza docenienie, dotychczas zarezerwowane wyłącznie dla artystów (mediatyzacja zachowań), z drugiej strony kieruje ku odbiorcy dedykacji, waloryzując więzi społeczne ważne z punktu widzenia ofiarodawcy dedykacji.

Nieco inny charakter ma poniższy uzus.

Obie świątynie są dedykowane Matce Bożej Łaskawej ${ }^{10}$.

Dedykowany Przemienieniu Pańskiemu kościól, [...], ozdobiono freskami w 1560 roku $^{11}$.

Święty Benedykt przekształcił świątynię w kaplicę, dedykując ją świętemu Marcinowi ${ }^{12}$.

Wszystkie powyższe użycia, nieobecne w polszczyźnie ogólnej i zapewne obce przeciętnemu użytkownikowi języka, oddać można za pomocą definicji opatrzonej obligatoryjnym kwalifikatorem religijny, mówiącej o poświęceniu w Kościele katolickim osobie boskiej, świętemu lub wydarzeniu religijnemu określonego rodzaju miejsca kultu. Choć w niektórych słownikach współczesnego języka angielskiego odnotowywane jest analogiczne (CED, $\mathrm{MW}^{13}$ ) lub nieco szersze zakresowo znaczenie $\left(\mathrm{MD}, \mathrm{OALD}{ }^{14}\right)$, dopatrywałabym się źródła tego rodzaju użyć w dzisiejszej polszczyźnie gdzie indziej, mianowicie w łacinie kościelnej. Jeżeli przeanalizujemy

${ }^{10}$ NKJP (b.d.): Ks. Józef Marecki, Bazylika Matki Bożej Łaskawej, „Głos Ojca Pio”, 2001-02.

11 NKJP (b.d.): Jan Gać, Grecja. Kulturowy przewodnik po Grecji bizantyńskiej, 2007.

${ }_{12}$ NKJP (b.d.): Jolanta Flach, Górale na Monte Cassino, „Tygodnik Podhalański”, nr 15, 1999.

${ }^{13}$ MW (b.d.): dedicate 1 to devote to the worship of a divine being; specifically: to set apart (a church) to sacred uses with solemn rites.

Tłumaczenie: poświęcić czci istoty boskiej; w szczególności: przeznaczyć (kościół) do użytku sakralnego za pomocą uroczystych obrzędów.

CED (b.d.): dedicate 5 to set apart for a deity or for sacred uses; consecrate.

Tłumaczenie: przeznaczyć bóstwu lub celom sakralnym; konsekrować.

${ }^{14} \mathrm{~W}$ definicjach szerszych zakresowo mowa jest nie tylko o miejscach kultu religijnego, lecz także o budynkach lub innych obiektach poświęconych osobom lub szczególnym celom, przy których lub wewnątrz których czci się określonego rodzaju pamięć, wyraża szacunek lub podziw, por.

MD (b.d.): dedicate $2 a$ to say at an official ceremony that a new building will have a special connection with a particular person as a sign of admiration or respect for them: a church dedicated to San Francis.

Tłumaczenie: stwierdzić podczas oficjalnej ceremonii, że nowy budynek zostaje poświęcony jakiejś osobie jako wyraz podziwu lub szacunku dla niej: kościół dedykowany Świętemu Franciszkowi. 
słowniki polskiej łaciny, zarówno średniowiecznej, jak i kościelnej współczesnej, okaże się, że wspomniane znaczenie było i jest obecne w tych opracowaniach ${ }^{15}$. Funkcjonuje zatem niezmiennie od wieków w łacinie, którą posługują się w Polsce osoby konsekrowane. Choć sens nieodnotowywany jest jako odrębny w słownikach współczesnego języka polskiego (wydanych po 1989 roku), posługujących się, jak to zostało wyżej zaznaczone, definicją wielokrotną, wzmiankowany był bez oddzielnej definicji w SJPD (1960, s. 46) za pomocą odpowiedniego cytatu: Po translacji relikwii św. Floriana do Krakowa ufundowat biskup Gedko kościót na Kleparzu, dedykowany temuż świętemu. Jak się wydaje, zarówno u swego źródła, jak i obecnie opisywany sens pozostaje w polszczyźnie w ścisłej zależności od łaciny kościelnej. Czasownik dedykować w tym znaczeniu występuje w NKJP wyłącznie w tekstach związanych poprzez osobę autora, tematykę tekstu lub wydawnictwo z Kościołem katolickim. Czemu znaczenie to nie zostało dotychczas odnotowane jako oddzielne w słownikach współczesnego języka polskiego? Być może winne temu są korpusy większych słowników, w których brakowało wydawnictw religijnych, lub nagminna praktyka przepisywania niedbałych definicji wielokrotnych (poświęcić, ofiarować) z wcześniejszych słowników, bez równoczesnego prowadzenia badań leksykologicznych.

Innego rodzaju użycia czasownika dedykować związane są z szeroko pojętym dyskursem retorycznym, np.

W świetle tych kilku przytoczonych przykładów nie sposób sobie wyobrazić, by miasto $\mathrm{z}$ tak podstawowymi mankamentami mogło kandydować do miana zwykłej letniskowej miejscowości, a co dopiero miasta olimpijskiego. Moje uwagi dedykuję panu burmistrzowi $[\ldots]^{16}$.

Stan, zachowanie i utrzymanie obiektów zabytkowych w dużej mierze zależy od inwencji gospodarza, jego przedsiębiorczości i kultury. I te słowa dedykujemy wszystkim gospodarzom polskich dworów, pałaców i rezydencji ${ }^{17}$.

OALD (b.d.): dedicate 3 to hold an official ceremony to say that a building or an object has a special purpose or is special to the memory of a particular person: The chapel was dedicated in 1880. A memorial stone was dedicated to those who were killed in the war.

Tłumaczenie: stwierdzić podczas oficjalnej ceremonii, że budynek lub obiekt ma szczególne przeznaczenie lub jest ofiarowany pamięci określonej osoby. Kaplica została poświęcona w 1880 roku. Obelisk upamiętnia tych, którzy zginęli w czasie wojny.

15 SŁŚ (b.d.): dedico 1 eccl. altare, ecclesiam sim.: poświęcać; consecrare, sacrum facere. Tłumaczenie: kościel. ołtarz, kościół i tym podobne: poświęcać; konsekrować, poświęcać. SK (1948, s. 163): dedico 1: konsekrować, poświęcić, przepisywać.

${ }^{16}$ NKJP (b.d.): Do burmistrza Zakopanego, „Tygodnik Podhalański”, nr 31, 1999.

17 NKJP (b.d.): Maria Irena Kwiatkowska, Marek Kwiatkowski, Krzysztof Wesołowski, Znane i nieznane: rezydencje, ludzie, wydarzenia, 2001. 
Jest rządowy program dotyczący transformacji kształcenia pielęgniarek i położnych w latach 2001-2005, lecz również i on nie niesie z sobą żadnych skutków finansowych w postaci pomocy na to kształcenie. Zwracam zatem uwage na nierówne traktowanie w naszym kraju różnych zawodów medycznych. Tę uwagę dedykuję ministrowi zdrowia ${ }^{18}$.

W powyższych fragmentach tekstów mamy do czynienia $\mathrm{z}$ użyciem o charakterze pragmatycznym (a nie systemowym), dla którego odpowiednią definicją wydaje się: skierować do kogoś określonego rodzaju wypowiedź, która spowodować ma zmianę sposobu myślenia lub postępowania odbiorcy. Oczywiście tego rodzaju uzus nie doczekał się dotychczas właściwego opisu leksykograficznego, nie wspominając o rozważaniach chronologicznych, dla których przyjęta w niniejszym artykule baza leksykograficzna oraz korpusowa jest niewystarczająca. Warto zatem w przyszłości przeprowadzić szczegółową kwerendę materiałową oraz słownikową, która pozwoliłaby scharakteryzować bliżej ten typ użyć.

Oprócz uzusu czasownika dedykować w znaczeniu podstawowym oraz w dwóch nadmienionych wyżej znaczeniach, pragmatycznym i związanym z językiem religijnym, szerzy się pod wpływem języka angielskiego dwojakiego rodzaju praktyka. Po pierwsze, czasownik ten znakomicie wyraża postulowaną w marketingu więź, która powinna zaistnieć między konsumentem i oferowanym mu produktem. Nie musi to wcale być konkretny przedmiot, może to być również usługa. Spójrzmy na poniższe użycia:

Sa mochody marki Volvo z grupy cross country są dedykowane dla ludzi aktywnych i ceniących komfort ${ }^{19}$.

Tym razem firma Quantum zaprezentowała dedykowaną najbardziej wymagającym użytkownikom serię dysków twardych Atlas $10 \mathrm{~K} \mathrm{II}^{20}$.

Ponadto operator będzie rozwijał usługi skierowane do konkretnych grup klientów (np. oferty dedykowane dla kobiet, oferty rodzinne) oraz udostępniał serwisy i gry społecznościowe ${ }^{21}$.

$\mathrm{W}$ ramach oferty dla wybranych grup zawodowych spółka proponuje usługi dedykowane dla lekarzy i weterynarzy $[\ldots]^{22}$.

${ }_{18}$ NKJP (b.d.): Sprawozdanie z 11. posiedzenia Senatu RP w dniu 6 marca 2002 r., 5 . kadencja.

19 NKJP (b.d.): (peR), Cross country na zimę, Express Ilustrowany, 2002-04-06.

${ }^{20}$ NKJP (b.d.): AP, DM, Shorty, „Enter”, nr 2, 2000.

${ }^{21}$ NKJP (b.d.): Krzysztof Gontarek, Polkomtel stawia na dbałość o klientów, „Dziennik Internautów", 2008-01-04.

${ }^{22}$ NKJP (b.d.): Leasingobiorcy chętnie korzystają z darmowego ubezpieczenia assistance, „Gazeta Ubezpieczeniowa”, 2010-06-16. 
Jeżeli weźmiemy pod uwagę kryteria fleksyjne, zauważymy, że w uzusie tym nie występują inne formy czasownika dedykować niż imiesłów przymiotnikowy bierny. $\mathrm{W}$ istocie jest to usamodzielniona znaczeniowo forma imiesłowowa o charakterze przymiotnikowym. Pod względem składniowym da się tutaj zaobserwować pewnego rodzaju rozchwianie pomiędzy formami syntetycznymi (imiesłów z rzeczownikiem w celowniku) oraz analitycznymi (imiesłów z przyimkiem dla oraz rzeczownikiem w dopełniaczu). Problem ten omawiany był wielokrotnie w krajowym językoznawstwie polonistycznym, zarówno w pracach poświęconych ewolucji systemu przypadkowego polszczyzny (por. Brodowska, 1955; Pisarkowa, 1984, ss. 104-105), jak i tych poświęconych konstrukcjom analitycznym (por. Anusiewicz, 1978; Cockiewicz \& Śliwiński, 1989). Dość nadmienić, że przyimek dla służy podkreśleniu osoby, odbiorcy przedmiotu lub usługi, będąc semantycznie bardziej wyrazistym narzędziem niż celownikowe formy rzeczowników o dość rozmytym i słabym znaczeniowo charakterze.

Nieco inaczej jest $z$ użyciami, które zaczęły szerzyć się w profesjolekcie informatycznym, znajdującym się, podobnie jak dyskurs reklamowy, pod wpływem współczesnej angielszczyzny. Tutaj określonego rodzaju urządzenie, tryb jego pracy, oprogramowanie lub jego wersja są zgodne z urządzeniem, trybem jego pracy, oprogramowaniem lub wersją tego oprogramowania, jak w poniższych przykładach.

Jak w poprzednim modelu Plextora, także tu producent wbudował wyrafinowane mechanizmy dedykowane nagrywaniu płyt o wysokiej jakości (PoweRec II), w tym także płyt audio (VariRec) ${ }^{23}$.

„Po prostu HTML 4” - to bez wątpienia jedna z najważniejszych książek poświęconych temu językowi. Trzecie już wydanie zawiera najświeższe informacje na temat XHTML, liczne porady niezbędne webmasterom opracowującym strony internetowe dedykowane urządzeniom przenośnym (palmtopom, telefonom komórkowym) ${ }^{\mathbf{2 4}}$.

W praktyce wymagane jest zakupienie specjalnej karty do komputera (z uwagi na mobilność rozwiązania najczęściej spotyka się karty dedykowane do laptopów) $[\ldots]^{25}$.

Firma Gigabyte wprowadziła na rynek nową płytę główną GA-2CEWH, dedykowaną dla procesorów AMD Opteron ${ }^{26}$.

${ }^{23}$ NKJP (b.d.): DK, Jakość gwarantowana, „Enter”, nr 1, 2003.

${ }^{24}$ NKJP (b.d.): Anna Wasilewska-Śpioch, Promocja i nowości wydawnictwa Helion, „Dziennik Internautów”, 2003-06-25.

${ }^{25}$ NKJP (b.d.): Krzysztof Surgut, Tania telefonia internetowa VoIP, 2006.

${ }^{26}$ NKJP (b.d.): 4press, Płyta główna zgodna z normami Unii Europejskiej, „Dziennik Internautów", 2005-09-07. 
Monika Biesaga Uzus a praktyka leksykograficzna (na przykładzie czasownika dedykować...

Aplikacja Ginger umożliwia sprawdzanie rozkładów jazdy linii komunikacji miejskiej w Poznaniu, Tychach i Białymstoku. Właśnie ukazała się jej wersja dedykowana na iPhone'a ${ }^{27}$.

Dzień, w którym będziemy mogli uruchomić na linuksie swoją ulubioną grę, dedykowaną pod Windowsa, zbliża się coraz bardziej ${ }^{28}$.

Podobnie jak w przypadku produktów i usług skierowanych do określonego rodzaju nabywcy, tutaj również nie występują inne formy czasownika dedykować niż imiesłowy przymiotnikowe bierne. Proces usamodzielnienia semantycznego imiesłowów dokonał się pod wpływem języka angielskiego (por. analogiczne znaczenie w haśle dedicated w OALD oraz $\mathrm{MW}^{29}$ ).

Dodatkowym argumentem, który potwierdza wpływ angielszczyzny w przypadku imiesłowowych neologizmów semantycznych, jest podział znaczeniowy użyć odpowiednika aspektowego analizowanego czasownika, czyli zadedykować. Realizują one znaczenie podstawowe czasownika, także o rozszerzonym współcześnie zakresie, por. poniższe przykłady:

Kiedy Maciej Papara zdecydował się zadedykować wystawę tatrzańskim ratownikom, nie wiedział o jubileuszu ${ }^{30}$.

- Żałuję, że nie zdobyłem bramki, bo chciałem ją zadedykować dziewczynie Marice $[\ldots]^{31}$.

Brak w NKJP uzusu sprzężonego z językiem kościelnym, odnaleźć można natomiast przykłady wystąpień o charakterze retorycznym, por.

Każdemu zaś poborowemu można zadedykować stare chińskie przysłowie: „Jak już spadłeś do piwnicy, to przynieś stamtąd kartofle"32.

${ }^{27}$ NKJP (b.d.): mk, Rozkład jazdy komunikacji miejskiej w iPhone'ach, „Dziennik Internautów", 2009-01-19.

${ }^{28}$ NKJP (b.d.): Krystian Zych, Pierwsze teksty Lindowsa, „Dziennik Internautów”, 2002-02-09.

${ }^{29}$ OALD (b.d.): dedicated 2 designed to do only one particular type of work; used for one particular purpose only. Software is exported through a dedicated satellite link.

Tłumaczenie: zaprojektowany, aby wykonywać określony rodzaj pracy; używany tylko do określonego celu. Oprogramowanie jest wysyłane poprzez dedykowane połaczenie satelitarne.

MW (b.d.): dedicated 2 given over to a particular purpose < a dedicated Web server $>$.

Tłumaczenie: przeznaczony do określonego celu <dedykowany serwer internetowy>.

${ }^{30}$ NKJP (b.d.): jof, Malarstwo czy fotografia, „Tygodnik Podhalański”, nr 33, 1999.

31 NKJP (b.d.): Katarzyna Koziarz, Michał2 Pol, Piłka nożna. Włochy: Polska 3.0 w eliminacjach MŚ '98, „Gazeta Wyborcza”, 1997-05-02.

${ }^{32}$ NKJP (b.d.): Marek Ciesielski, Paweł Siekański, Arkadiusz Znojek, 540 DDC, czyli jakie jest wojsko, 2000. 
Natomiast zupełnie akcydentalnie spotkać można uzus o charakterze neosemantycznym, co znamienne, wyłącznie z rekcją celownikową, por.

Czas poświęcany na wędrówki po Sieci w domu zazwyczaj uzupełniamy godzinami on-line w pracy. Coraz częściej, dzięki odpowiednim programom monitorującym, kończy się to smutno dla „uzależnionych” od tego typu węd rówek, szczególnie gdy zaglądają na strony zadedykowane dorosłym ${ }^{33}$.

Brak symetrii znaczeniowej odpowiedników aspektowych da się wytłumaczyć różnicami morfologicznymi występującymi w języku angielskim i języku polskim. Czasowniki angielskie nie tworzą par aspektowych, a dokonanie bądź niedokonanie czynności oddawane jest za pomocą formy czasu przeszłego czasownika (past simple, past participle), pełniącej funkcję przydawki lub wchodzącej w skład odpowiedniej konstrukcji czasowej. W języku polskim natomiast czasowniki wyrażają aspekt dokonany lub niedokonany (czasem oba jednocześnie). Dlatego nowe, zapożyczone z angielszczyzny użycia imiesłowowe typu dedykowany w zasadzie nie mają swojego odpowiednika zadedykowany, ponieważ kategorię aspektu dokonanego wyrażają w interesującym nas uzusie usamodzielnione formy imiesłowów biernych w funkcji przydawek bądź formy te wchodzące w skład orzeczeń złożonych, podobnie jak czynią to w języku angielskim formy past simple oraz past participle.

Pod względem składniowym w przypadku wystąpień pochodzących z tekstów informatycznych zaobserwować można większą różnorodność uzusu pod względem rozczłonkowania. Obok połączenia imiesłowu z rzeczownikiem w celowniku o charakterze syntetycznym stosowanych jest kilka typów konstrukcji analitycznych, mianowicie imiesłów z przyimkiem dla i rzeczownikiem w dopełniaczu (najczęstszy typ konstrukcji), imiesłów z przyimkiem do i rzeczownikiem w dopełniaczu (typ o pośredniej liczbie wystąpień), imiesłów z przyimkiem pod i rzeczownikiem w bierniku (typ rzadki) oraz imiesłów z przyimkiem na i rzeczownikiem w bierniku (typ również rzadki, niemniej jednak odnotowany, między innymi również we wspomnianym artykule Jana Miodka). Bogactwo konstrukcji analitycznych związane jest z semantyką imiesłowu dedykowany w tym znaczeniu. Gdyby szukać polskich ekwiwalentów tego neosemantyzmu, wymienić można cały ich szereg, na przykład przeznaczony, odpowiedni, właściwy, dostosowany i tak dalej. W istocie za każdym razem, gdy wyrazić chcemy zgodność przeznaczenia jednego obiektu w stosunku

${ }^{33}$ NKJP (b.d.): Włodzimierz Gogołek, Kasa w Sieci, „Enter”, nr 2, 2000. 
do drugiego, użyć możemy etykiety językowej dedykowany, z czym wiąże się również leseferyzm komunikacyjny w doborze przyimków wyrażających celowość, przeznaczenie. Stosowaniu imiesłowu dedykowany sprzyja również błyskawiczny przyrost liczby urządzeń informatycznych, dla których nazw trudno znaleźć właściwy wzorzec uzusu językowego.

Dzięki swej pojemności semantycznej imiesłów dedykowany przekroczył granice dyskursów reklamowego i informatycznego, co ilustrują poniższe, mniej lub bardziej dewiacyjne językowo, przykłady.

Dlatego na rynku dostępnych jest mnóstwo specjalnych olejów dedykowanych do silników na gaz ${ }^{34}$.

Podjęta została decyzja o wyodrębnieniu z dotychczasowej struktury organizacyjnej [...] Departamentu Ubezpieczeń Korporacyjnych i Frontingu (DUKF), nad którym nadzór sprawować będzie dedykowany członek zarządu ${ }^{35}$.

Planuje się obecnie wykonanie specjalnych, dedykowanych eksperymentów, aby wyjaśnić to zagadnienie ${ }^{36}$.

[...] guma ze Skarbimierza nie jest dedykowana na kraj, tylko na świat, Europę Zachodnią, Bliski Wschód i Afrykę ${ }^{37}$.

Jak się wydaje, bez względu na rozpiętość zakresową usamodzielnione semantycznie imiesłowowe użycia wszystkich typów oddać można za pomocą wspólnej, dość pojemnej eksplikacji, np. „taki, który ze względu na swoje cechy lub umiejętności jest najbardziej odpowiedni do pełnienia określonego rodzaju funkcji”.

Jeżeli chodzi o zagadnienia poprawności językowej, analizowane neosemantyzmy imiesłowowe, znamienne dla marketingu oraz informatyki, uznać należy za rażąco nadużywane we współczesnym języku polskim, czemu sprzyjają: język ich pochodzenia (zagadnienie prestiżu komunikacyjnego), pojemność semantyczna oraz nieostry znaczeniowo i rozchwiany składniowo uzus. Myślę, że językoznawcy w miarę swoich możliwości (kontakt ze studentami, strony internetowe, spotkania popularyzatorskie) powinni podjąć ten temat.

${ }^{34}$ NKJP (b.d.): Bartosz Gubernat, Jak wybrać odpowiedni olej silnikowy?, „Gazeta Pomorska", 2010-03-12.

35 NKJP (b.d.): Bożena M. Dołęgowska-Wysocka, Plusy i minusy fuzji na polskim rynku, "Gazeta Ubezpieczeniowa”, 2007-02-20.

${ }^{36}$ NKJP (b.d.): Adam Strzałkowski, O siłach rządzących światem: rzecz o podstawowych oddziaływaniach - grawitacyjnych, elektromagnetycznych, silnych i słabych, 1996.

37 NKJP (b.d.): Edyta Gietka, Tajemnice gumy do żucia we wsi Skarbimierz, „Polityka”, nr 2696, 2009-03-14. 
Oczywiście nie da się wyeliminować tego rodzaju wystąpień w socjolektach branżowych. Warto jednak podkreślać, że nie są to konstrukcje aprobowane w polszczyźnie ogólnej, a już z pewnością nie są składową odmiany książkowej, jak mogłoby się wydawać osobom utożsamiającym pod względem rejestru wypowiedzi znaczenie podstawowe czasownika dedykować z wzorowanymi na języku angielskim konstrukcjami imiesłowowymi.

Podsumowując, problem zróżnicowania i ewolucji użyć czasownika dedykować jest o wiele szerszy i bardziej złożony, aniżeli wynikałoby to z pobieżnej analizy. Jak się okazuje, wcześniejsze słowniki języka polskiego, ze względu na niewystarczającą wielkość baz materiałowych bądź ich brak, niechęć do uwzględniania sensów kontekstowych (na przykład pragmatycznych), a czasem wtórność opisu, pomijają szereg funkcjonujących w języku znaczeń. Jeżeli chodzi zaś o neologizmy semantyczne, ich charakterystyka powinna pozostawać w ścisłym związku z analizą danych korpusowych. Słowniki akademickie języka stanowiącego źródło zapożyczenia stanowią cenną, choć niewystarczającą pomoc. W przypadku najnowszych zmian semantycznych ewolucja użyć jest tak szybka i zróżnicowana, że nawet słowniki współczesnej angielszczyzny nie nadążają z jej uchwyceniem w swoim kręgu kulturowym. Jak się okazuje, kompilowanie opracowań leksykograficznych w oparciu o wcześniejsze słowniki oraz słowniki języków-matek najnowszych znaczeń jest niewystarczające. Nic nie zastąpi bowiem starannej analizy danych korpusowych, do której należy zachęcać osoby chcące zajmować się semantyką leksykalną.

\section{Bibliografia}

Anusiewicz, J. (1978). Konstrukcje analityczne we współczesnym języku polskim. Wrocław: Ossolineum.

Bańko, M. (2001). Z pogranicza leksykografii i językoznawstwa: Studia o słowniku jednojęzycznym. Warszawa: Nakładem Wydziału Polonistyki Uniwersytetu Warszawskiego.

Bańko, M. (Red.). (2000). Inny słownik języka polskiego [ISJP] (T. 1). Warszawa: Wydawnictwo Naukowe PWN.

Brodowska, M. (1955). Historyczne procesy przekształceń polskiego celownika w formy przyimkowe. Studia z Filologii Polskiej i Słowiańskiej, 1, 9-58.

Cockiewicz, W., \& Śliwiński, W. (1989). Właściwości składniowo-stylistyczne języka telewizji polskiej (na materiale list frekwencyjnych). (Z. Kurzowa, Red.). Warszawa: Państwowe Wydawnictwo Naukowe. 
Monika Biesaga Uzus a praktyka leksykograficzna (na przykładzie czasownika dedykować...

Collins English Dictionary [CED]. (b.d.). Pobrano 1 kwietnia 2016 z http://www.collinsdictionary.com/

Doroszewski, W. (Red.). (1960). Słownik języka polskiego [SJPD] (T. 2). Warszawa: Państwowe Wydawnictwo Wiedza Powszechna.

Dubisz, S. (Red.). (2003). Uniwersalny słownik języka polskiego [USJP] (T. 1). Warszawa: Wydawnictwo Naukowe PWN.

Dunaj, B. (Red.). (1996). Słownik współczesnego języka polskiego [SWJP]. Warszawa: Wydawnictwo Wilga.

Elektroniczny słownik łaciny średniowiecznej w Polsce (A-Q) [SŁŚ]. (b.d.). Red. M. Rzepiela et al. Pobrano 1 kwietnia $2016 \mathrm{z}$ http://scriptores.pl/elexicon/

Jougan, A. (1948). Słownik kościelny łacińsko-polski [SK] (2. wyd.). Przemyśl: Michalineum.

Macmillan Dictionary [MD]. (b.d.). Pobrano 1 kwietnia $2016 \mathrm{zhttp} / /$ www.macmillandictionary.com/

Merriam-Webster Dictionary [MW]. (b.d.). Pobrano 1 kwietnia 2016 z http://www.merriamwebster.com/

Miodek, J. (2013). Składniowe paradoksy leksykalnych kalk. Język Polski, 93(2), 118.

Miodek, J. (2014, październik 25-26). Dedykować, seria: Między słowami. Gazeta Wyborcza, s. 49.

Narodowy Korpus Języka Polskiego [NKJP]. (b.d.). Pobrano 1 kwietnia 2016 z http://www.nkjp.pl/

Oxford Advanced Learner's Dictionary [OALD]. (b.d.). Pobrano 1 kwietnia $2016 \mathrm{z}$ http://www. oxfordlearnersdictionaries.com/

Pisarkowa, K. (1984). Historia składni języka polskiego. Wrocław: Zakład Narodowy im. Ossolińskich, Wydawnictwo Polskiej Akademii Nauk.

Polański, E. (Red.). (2012). Wielki słownik języka polskiego [WSJP KWN]. Kraków: Krakowskie Wydawnictwo Naukowe.

Zgółkowa, H. (Red.). (1996). Praktyczny słownik współczesnej polszczyzny [PSWP] (T. 8). Poznań: Wydawnictwo Kurpisz.

\section{Rozwiązania skrótów}

$\begin{array}{ll}\text { CED } & =\text { Collins English Dictionary, www.collinsdictionary.com } \\ \text { ISJP } & \text { Inny słownik języka polskiego, red. M. Bańko, Wydawnictwo Naukowe PWN, } \\ & \text { Warszawa 2000, t. 1, s. 249. } \\ \text { MD } & \text { Macmillan Dictionary, www.macmillandictionary.com } \\ \text { MW } & \text { Merriam-Webster Dictionary, www.merriam-webster.com } \\ \text { NKJP } & \text { Narodowy Korpus Języka Polskiego, www.nkjp.pl } \\ \text { OALD } & \text { Oxford Advanced Learner's Dictionary, www.oxfordlearnersdictionaries.com } \\ \text { PSWP } & \text { Praktyczny słownik współczesnej polszczyzny, red. H.Zgółkowa, Wydawnictwo } \\ & \text { Kurpisz, Poznań 1996, t. 8. } \\ \text { SJPD } & \text { Słownik jezzyka polskiego, red. W. Doroszewski, Państwowe Wydawnictwo } \\ & \text { Wiedza Powszechna, Warszawa 1960, t. 2. }\end{array}$



SK = Słownik kościelny łacińsko-polski, Alojzy Jougan, Michalineum, Przemyśl 1948, wyd. II, s. 163.
SŁŚS = Elektroniczny słownik łaciny średniowiecznej $w$ Polsce $(A-Q)$, red. M. Rzepiela et al., http://scriptores.pl/elexicon/
SWJP = Słownik współczesnego języka polskiego, red. B.Dunaj, Wydawnictwo Wilga, Warszawa 1996, s. 159.
USJP = Uniwersalny słownik języka polskiego, red. St. Dubisz, Wydawnictwo Naukowe PWN, Warszawa 2003, t. 1.
WSJP KWN = Wielki słownik języka polskiego, red. E. Polański, Krakowskie Wydawnictwo Naukowe, Kraków 2012.

\section{Usage and lexicographical practice (example of the verb dedykować 'to dedicate' in modern Polish)}

\section{Summary}

The purpose of this paper is to analyze the contemporary usage of the Polish verb dedykować (to dedicate) and its participle dedykowany (dedicated). During last few years under the influence of English semantics and pragmatics this verb became one of the most popular words in the Polish marketing and IT jargon. The data provided by the National Corpus of Polish enables to state that the contemporary usage of the verb differs significantly from the semantic description published in the dictionaries of Polish. Therefore the scope of this paper is to promote the corpus driven approach to the lexicography. Since the new meaning of the analyzed verb is an English borrowing the paper deals also with the problem of adjusting English morphological patterns to the rules of Slavic verbal inflexion. As it can be observed in the text this grammatical divergence leads in the case of new borrowings to the widely diversified and unstable language usage. 


\section{Uzus a praktyka leksykograficzna (na przykładzie czasownika dedykować we współczesnej polszczyźnie)}

\section{Streszczenie}

Celem artykułu jest analiza występujących we współczesnej polszczyźnie użyć czasownika dedykować. Szczególną uwagę językoznawców zwróciły w jego przypadku neologizmy semantyczne typu dedykowany, których nowe znaczenie, znamienne dla języka marketingu oraz profesjolektu informatycznego, zapożyczone zostało z języka angielskiego. Dane korpusowe umożliwiły stwierdzenie, że czasownik ten używany jest również w innych znaczeniach, nieoddanych dotychczas w odpowiedni sposób w słownikach współczesnego języka polskiego, zaś same neosemantyzmy cechuje niezwykle rozchwiany pod względem semantycznym oraz składniowym uzus.

Keywords: semantic neologism; English borrowing; analytical construction; lexicography; participle

Słowa kluczowe: neosemantyzm; anglicyzm; analityzm; leksykografia; imiesłów

Monika Biesiaga, Institute of the Polish Language, Polish Academy of Sciences, Cracow

Correspondence: monika.biesaga@interia.pl; www.researchgate.net/profile/Monika_Biesaga

This work has been self-funded by the author.

Competing interests: The author has declared she has no competing interests. 